\title{
Rethinking Contract Practice and Law in Japan
}

\author{
John O. Haley*
}

This article explores "the Japanese advantage" in the enforcement of ex ante contract commitments in comparison with the United States, arguing that ostensible convergence of Japanese and United States contract practice in on - going business relationships is based on very different assumptions and conditions. Writing in the early 1960s Takeyoshi Kawashima in Japan and Stewart Macaulay in the United States described prevailing views and practices related to business agreements. Their respective observations indicated a tendency in both countries to avoid formal, legally enforceable contacts. For over four decades scholars on both sides of the Pacific have tended view these observations as grounds for arguing for a convergence of contract practice. Recent research efforts have attempted to verify empirically such convergence. On closer examination, however, the conclusions reached by Kawashima and Macaulay rest on very different assumptions. For Kawashima the avoidance of formal contact appears to be based on a desire to avoid the enforcement of ex ante commitments by those who perceive that their bargaining leverage will remain intact throughout an on - going business relationship, thus enabling them to adjust unilaterally to changing circumstances. Similarly enforceable ex ante contractual commitments may also be viewed as less advantageous to those who may have the disadvantage in bargaining leverage at the time of the contracting to the extent that they perceive that they may gain greater ex post leverage. Macaulay, on the other hand emphasized the transactions costs of formal contracting and uncertainty of enforcement that reduced the efficacy of ex ante commitments. This article explores the predicates for both positions. It concludes that with respect to the concerns raised by Macaulay, Japan has a comparative advantage. Because of the organization and values of Japanese judges as well as the legal rules related to both excused non-performance as a result of changing circumstances, the legal rules favor greater certainty in the enforcement of ex ante commitments thereby supporting Kawashima's foundational observations. Similarly, the greater uncertainty of enforcement as well as the flexibility of the legal rules on impracticability as well as contract termination in the United States justifies

* Wiley B. Rutledge Professor of Law at Washington University School of Law in St. Louis. A.B.(Princeton), J.D.(Yale), LL.M.(Univ. of Washington). This paper was presented at the Fourth International Conference on Contracts held at the McGeorge School of Law, University of the Pacific, Sacramento, California, Feb. 8-9, 2008 . 
Macaulay's conclusions. Japan's loss of advantage in terms of effective formal enforcement of contract rights, it is argued, is counter-balanced by the strength of supportive mechanisms of private ordering.

\section{Introduction}

In no area of Japanese law have conventional views of Japanese practice and the apparent irrelevance of law established a half century ago persisted so durably as with contract. Takeyoshi Kawashima, the Japanese law scholar whose influence on post WWII perceptions of Japanese law and legal culture remain unparalleled, articulated best the prevailing view. Coining the phrase "legal consciousness" (höishiki), he wrote, that Japanese still clung to traditional patterns and attitudes toward law and contracts, preferring vaguely defined terms and indeterminate commitments that preclude legal enforcement and allow future flexibility and adjustment. Thus, he asserted, ex ante commitments as clearly articulated legal rights and duties are "unsettling" (fuan) for most Japanese. ${ }^{1}$ Kawashima was apparently unaware of the contemporaneous and equally seminal work by Stewart Macaulay on relational contracting and business practice in the United States. ${ }^{2}$ Accepting the basic arguments of both Kawashima and Macaulay comparative lawyers and students on both sides of the Pacific have subsequently devoted almost exclusive attention to the question of whether or in what ways Japan does in fact differ from the United States or other "modern" industrial states, particularly in the extent to which relational contracting without legally enforceable commitments prevails. ${ }^{3}$ One of the most ambitious attempts in this regard was a project in the mid 1990s led by University of Tokyo Professor Takashi Uchida under the auspices of the Center for Global Partnership (Japan Foundation) to develop

1 KaWAShima TAKeyoshi, NihonjIn no HōIshikI (Legal Consciousness of Japanese) 117 (1967). For a Charles R. Stevens' translation of Kawashima' s chapter on the "Legal Consciousness of Contract in Japan," see 7 LAW IN JAPAn: An Annual 1 (1974). See also Takeyoshi Kawashima, The Status of the Individual in the Notion of Law, Right, and Social Order in Japan, in C. A. Moore, ed., THE JAPANESE Mind 262-87 (1968).

2 See Stewart Macaulay, Non-Contractual Relations in Business: A Preliminary Study, 28 Am. SociologiCAL REv. 55 (1963).

3 See e.g., J. Toshio Sawada, Subsequent Conduct and Supervening Events 162-226 (1968); Hiroshi Wagatsuma and Arthur Rosett, Cultural Attitudes Towards Contract Law: Japan and the United States Compared, 2 UCLA PAC. BASIN L. J. 76 (1983); Whitmore Gray, The Use and Non-use of Contract Law in Japan: A preliminary Study, 17 LAW IN JAPAN: AN ANNUAL 119 (1984), reprinted in J.O. HALEY, ed., LAW AND Society in Contemporary Japan: American Perspectives 243-62 (1988); Gordon Matei, Challenging the Myths: Japanese and CANAdian AtTitudes Toward Commercial Contracts (unpublished student paper, University of British Columbia, c1990); Shinichirō Michida, Contract Societies: Japan and the United States 
empirical data on the similarities and possible differences in Japanese and U.S. contract practice. ${ }^{4}$ Uchida and his team have so far had the last word. No one else has endeavored to replicate their effort or even to question seriously the basic premises and propositions of Kawashima's and subsequent studies. With the exception of Luke Nottage' s surveys of long-term contract practices in New Zealand 5 and Gordon Matei' s unpublished student paper on Canadian practice for a class in Japanese law at the University of British Columbia, 6 all attempts to develop empirical data have apparently focused on a U.S. comparison. Remarkably, no similar efforts, to my knowledge, have been undertaken in either Germany or South Korea despite their greater similarity with Japan in terms of law, economic growth, and, in the case of South Korea, cultural heritage. Equally if not more significant no subsequent study has addressed the fundamental question of why any of this matters other than with respect to an ill-defined concern with the relevance of legal rules. Since the 1960s U.S. scholars have largely ignored substantive contract law.

Kawashima, it should be recalled, had a vision in mind. Heavily influenced by Talcott Parsons's notion of progression from traditional to modern societies, he understood the question in terms of social and economic change. He emphasized what he considered to be traditional attitudes and behavior. He forecast their transformation as Japan inexorably converged with "modern" Western patterns as a result of economic development and what we today refer to as "globalized" markets. By current standards Kawashima's views of Japanese contract practice seems almost quaintly anecdotal and impressionistic. Unlike his often-cited observations on Japanese dispute resolution, initially published in English7 but subsequently also included as a chapter in his book on Japanese legal consciousness,, 8 he provided no empirical support for his views on

Contrasted, 1 PAC. RIM L. \& PoL' Y J. 199 (1992), translated by Veronica Taylor \& Michael J. Smitka, Contracting Without Contracts: How Japanese Manage Organizational Transactions, in S.B. SiTKIN \& R.J. Bies, eds., The Legalistic Organization 91-108 (1994); Zentaro Kitagawa, Use and Non-Use of Contracts in Japanese Business Relations: A Comparative Analysis, in H. BAuM, ed., JAPAN: ECONOMIC Success AND LEGAL SYsTem 146-65 (1997); Luke R. Nottage, Contract Law and Practice in Japan: An Antipodean View-Revisited, 31 HIKAKUHō ZASSHI [Comparative Law Journal] 55 (1997).

4 For details of the study and its findings, see Takeshi Uchida, KIYAKUHō NO GENDAIKA [Bring contract law upto-date] NBL (No. 584) 4 (1996) ; John O. Haley, Relational Contracting: Does Community Count?, in HaRALD BAUM, JAPAN: ECONOMIC SUCCESS AND LEGAL SYSTEM 167-83 (1996).

5 Luke Nottage, Planning and Renegotiating Long-Term Contracts in New Zealand and Japan: An Interim Report on an Empirical Research Project, New ZEALAND L. Rev. 482 (1997); Luke R. Nottage, Economic Dislocation and Contract Renegotiation in New Zealand and Japan: A Preliminary Empirical Study, 27 Victoria Univ. WeLLINGTON L. REV. 59 (1997).

6 Matei, supra note 3.

7 Takeyoshi Kawashima, Dispute Resolution in Contemporary Japan, in A.T. vON MeHREN, ed., LAW IN JAPAN: The Legal Order In A Changing Society 41-72 (1963).

8 Kawashima, NIHONJIN NO HŌISHIKI, 125-203(chap. 5). 
contract practice. He relied instead on personal experience and narrative. Given the subsequent emphasis on relational contracting, a rereading of Kawashima may surprise some. Nowhere does he mention on-going business relationships or private ordering. His concern was what he observed as a tendency to avoid clarity and legally enforceable rights and duties with a concomitant desire to maintain flexibility in light of supervening events. His description of "traditional" values and contract practices was also closely related to his views on Japanese preference for conciliated settlements and reluctance to litigate. Japanese contract practices reflected an asserted aversion to lawsuits. Adopting a Parsonian view of traditional societies in the process of "modernization," he emphasized, however, that Japanese practices were likely to change as society became increasingly commercialized and influenced by western practice.

Most scholars today would dismiss as naïve his notion of institutional change along with his assumption of a linear progression from a "traditional" to a "modern" society. Nonetheless, an unspoken premise - the lemma, if you will-of most of not all subsequent research has been a view of Japanese practice as a product of the past, an aspect of embedded values habits, and social structures, inexorably subject to change and convergence with the more "advanced" economic and legal orders of the West, (mis)represented, of course, by the United States. In a sense, findings of similarity confirm at least for some that Japan has indeed already converged and has become fully "modern" to use the unfashionable term. Largely if not completely ignored are other issues and implications. Among them is an issue fundamental to the Kawashima thesis - the contribution of contract practice and law to economic growth. Behind the Parsonian dichotomy his concern is evident: Contract practices and legal rules-as articulated and enforced by the courts - both reflect and contribute to economic change. Kawashima's focus thus presages the interest of contemporary economists-especially those identified with the "new institutional economics" led by Douglass North - who argue that certainty and predictability of enforcement of contracts along with property rights are significant factors in economic growth. As growth-fostering institutions the legal rules and their enforcement matter greatly. For North "key" to the effort to improve economic performance is thus "the creation of an effective judicial system to reduce the costs of contract enforcement." 9 Add "path dependency," another of North' s emphases, 10 and one can reformulate Kawashima' s argument in more acceptable contemporary phraseology - to what extent do embedded Japanese institutions constrain economic growth by restricting the development of contract rights and the predictability of their enforcement. Taken a face value the findings by Uchida, Nottage, and others suggest that for whatever reason Japan is no more constrained than the 
United States. In other words, their convergence, whatever the cause, places both countries in relative parity.

Having some years ago questioned Kawashima's conclusions regarding a generalized Japanese propensity to avoid litigation. 11 I would like here again to take issue with Kawashima's views with, however, renewed admiration for his insight as to what is at state. My purpose, as indicated in the title of this paper, is to rethink Japanese contract practice and law. In so doing I do not question current understandings regarding contract practice in either Japan or the United States. Rather, I would like to reconsider in comparative terms the role of law and law enforcement both present and the past. To state my conclusion at the outset, Japan has the comparative advantage.

\section{Contextual Contrast and Similarities}

Most attempts to compare the role of law and law enforcement in Japan and the United States, including the studies on contract practices noted above, as well as in other discrete areas such as litigation,12 are thwarted by the threshold hurdle of contextual contrasts. Neither similarities in contract practices nor differences in litigation rates can be meaningfully understood without taking into account multiple variables and significant institutional and structural differences. For this reason I have explicitly eschewed U.S. and other national comparisons in my own studies of litigation in Japan.13 If the question posed is whether economic actors in either Japan or the United States enjoy meaningfully greater certainty and predictability in transactional security and the enforcement of contract rights, many of these variables become individually and collectively significant. They include the substantive legal rules themselves as well as the degree of legal awareness of these rules within the community of economic actors - as well as the perceptions of certainty the parties share with respect to the enforceability of their ex ante agreements. Hence the clarity and degree of knowledge of the law as reflected in its dissemination as well as the effectiveness of judicial

10 Douglas R. North, Institutions, Institutional Change and Economic Performance (1990).

11 John O. Haley, The Myth of the Reluctant Litigant, 4 J. JAPANESE STUD. 359 (1978), translated into Japanese by Judge Shintarō Kato in HANREI JiHō((No. 902) 14, (No. 907) 13 (1978).

12 See, e.g., Christian Wollschläger, Historical Trends of Civil Litigation in Japan, Arizona, Sweden, and Germany: Japanese Legal Culture in Light of Judicial Statistics, in H. BAUM, ed., JAPAN: Economic Success, supra note 3 , at 89.

13 See Haley, supra note 10, at 362-364; also John O. Haley, Litigation in Japan: A New Look at Old Problems, 10 WiLlamette J. InT'L L. \& Dispute Resolution 121 (2002). 
enforcement are among the most obvious points of comparison. Other cultural and structural variables are also significant. Levels of trust as well as the extent and functions of private ordering also influence contractual behavior-either by creating substitute systems of ordering that diminish the role of substantive legal rules or by providing alternative mechanisms for their enforcement thereby enhancing their efficacy. The endeavor thus becomes a demanding holistic effort, one that is well beyond my aim in this paper. Nevertheless, having studied the Japanese legal system from an American perspective for four decades, I would like to make some informed observations and to suggest some tentative conclusions.

First, looking backwards with features of the contemporary legal system in mind, we can easily identify features of past practice and law that tend to confirm Kawashima's basic emphasis on continuity although neither his construction of history nor predictions of the future. A summary of past research will hopefully suffice. Briefly stated, Japan had developed the means to ensure greater certainty relative to the Western Europe and the United States in the enforcement of contracts long before its successful adoption of westernized legal reforms of the late 19th century. By the 16th century Japan had developed both adjudicatory institutions and a corpus of both customary commercial law and contract in the interstices of a sinofied administrative order. ${ }^{14}$ As evidenced by John Henry Wigmore' s multivolume compendium of law under Tokugawa rule (1603-1867),15 Japanese commercial law comprised a highly developed corpus of rules and practices enforced by state adjudicatory institutions. Hence Japan's "path dependency” supported its westernizing trajectory toward structures and institutions that supported rather than retarded economic growth. Where Kawashima saw conflict and change, I suggest accommodation and progression, with, I should hasten to note, much the same end.

\section{The Japanese Advantage}

Broader economic and social attributes attest to the Japanese advantage. Japan has the third largest industrial economy. Only the United States and China, because of population, loom larger. The Japanese today enjoy one of the highest standards of living on the globe. Japan's per capita income, literacy rates, and equal distribution of wealth

14 See Carl Steenstrup, A History of LaW in Japan UntIL 1868 100-7 (1991).

15 John Henry Wigmore, LaW and Justice in TokugaWa Japan: Materials for the History of Japanese LaW AND JUSTICE UNDER THE TOKUGAWA SHOGUNATE, 1603-1867 (1967-). 
in combination surpass all but a few small European states. With a population a third larger than Germany and larger than France and the United Kingdom combined, at $\$ 28,000$ in 2004, Japan's per capita GNP was higher than any of the three largest European nations. 16 Even more significant, as measured by UN Gini indices, Japan ranks just behind Denmark and Finland but just ahead of Norway and Sweden.17 OECD data rank Japan a bit lower.18 At worst Japan is slightly behind the welfare states of Europe but on par with Canada and the United Kingdom. To complete the picture its literacy rate is the highest recorded. 19

With respect to transactional security and certainty economic actors in Japan have special advantages in comparison with their counterparts in the United States. Reflecting civilian, especially German approaches, the principles and rules of contract law are more favorable than U.S. law to enforcement of agreements. This is especially true with respect to formation and performance. The remedial rules too tend to encourage enforcement. The formal rules of Japanese contract law have greater clarity and are arguably more widely known and accessible than in the United States. Japanese also enjoy significant advantages in judicial enforcement. Only with respect to the capacity of the courts to enforce their judgments do contract claimants in the U.S. appear to have a comparative advantage. However, trust, reputation, and a variety of informal social controls and private ordering mechanisms appear to provide effective substitutes for the relative weakness of civil enforcement. Let me turn to each of these factors in more detail.

\section{The Judiciary}

The judiciary is central to all evaluations of contract practice and law. Adjudication in all legal systems is both a law-making and law-enforcing process. Judges are thus primary actors in the articulation, recognition, creation and enforcement of legal rules. Both Kawashima and North emphasize, correctly in my view, that the efficacy of law

16 In Europe only Luxembourg (\$55,100), Norway $(\$ 37,800)$, Switzerland $(32,800)$, Denmark $(\$ 31,200)$, Austria $(\$ 30,000)$, and Belgium $(\$ 29,000)$ had higher per capita incomes. Although the difference is slight Japan's per capita income is higher than the United Kingdom $(\$ 27,700)$, Germany $(\$ 27,600)$, France $(27,500)$, Italy $(\$ 26,800)$ as well as Sweden $(\$ 26,800)$. See http://www.worldfactsandfigures.com (last visited on Jan. 14, 2007).

17 http://hdr.undp.org/reports/global/2003/indicator/indic_126_1_1.html (last visited on Jan. 14, 2007).

18 http://www.oecd.org/dataoecd/12/4/35445297.xls (last visited on Feb. 7, 2007).

19 http://www.literacyonline.org (last visited on Jan. 14, 2007). 
depends first and foremost on the judiciary. By all objective criteria Japan' s judges are among the world's most competent, most trusted and certainly most honest on the globe. ${ }^{20}$ Apparently unique organizational features also contribute to an equally unsurpassed degree of legal certainty and predictability. As in other civil law systems, Japan has a career judiciary. It is a unitary national system. The number of judges approximately 3000 - is by any measure small. Each judge is assigned to courts at all levels for limited periods of time by a central personnel office staffed by career judges similarly assigned in the General Secretariat. All judges begin their careers today with a three-year posting with either the Tokyo or Osaka district courts. Assignments then vary, but each judge will have served in one or more family courts (district court level), usually one or more high courts, perhaps one or more administrative posts in the General Secretariat, generally ending a twenty - five to thirty - five year career as a chief judge of a district or high court, a few as president (chōkan) of a high court, and even fewer, after retirement with an imperial appointment to the Supreme Court. Nearly all litigated cases require a three judge panel, usually comprising at least one senior judge with one or two mid or early career judges. Lacking a civil jury, these panels must reach collective decisions with respect to both facts and law. All judgments include both findings of fact and the applicable law as well as the rationale for the ultimate decision. All are transmitted to the appropriate division in the General Secretariat to be reviewed for publication.

Transactional security, certainty, predictability, and a consequent adherence to precedent are deeply embedded judicial values. ${ }^{21}$ Judges are also principal makers of contract law. Aside from Supreme Court en banc and, to a lesser extent, petty bench decisions, formally no single court decision has precedential value. Nevertheless, the courts have long played a dominant role in developing the law through both the construction of provisions of the Civil Code 22 as well as the recognition and application of principles drawn from other sources.23 Moreover, courts at all levels participate in the process. The hierarchical structure of the court system, as one might expect, dictates that second instance high court decisions are generally more authoritative than first instance district court decisions. The relative deference, however, is not as great as in other legal

John O. Haley, The Japanese Judiciary: Maintaining Integrity, Autonomy and Public Trust, in DanIeL H. Foote, ed., Law in JaPan: in Daniel H. Foote, ed., A Turning Point (2007).

21 See John O. Haley, The SPIRIT OF JAPANESE LaW 114-22 (1998).

22 Mimpō (Law No. 89, 1896).

23 For example, the overarching requirement of article 1 of the Civil Code that the exercise of private law rights not violate "public order and good morals," "good faith" or constitute an "abuse of rights" was added as a postwar amendment (Law No. 222, 1947). Each of these principles had been recognized decades earlier in Japanese decisional law. 
systems. Career judges in Japan are assigned to both first and second instance courts throughout the country at various times during their professional careers. As a result, senior judges in the district courts are likely to have served previously as judges in one or more high courts. Hence, district court decisions carry considerable weight, particularly when the presiding judge (of the usual three judge panel) is highly regarded. Nevertheless, high court decisions signal both continuity and change in Japanese law. High court affirmation on appeal of a district court decision in conformity with generally accepted principles evidences their continuing vitality throughout the legal system. High court affirmation of a decision that departs from generally accepted outcomes signals the advent of legal innovation and change. Conversely, high court reversals function as an equally influential signal and check on unwanted change. Although more rare, a high court reversal may also signal change where the district courts have been perhaps more timid.

Judicial decisions area also easily accessible and widely disseminated. In terms of the penetration of legal knowledge and expertise, Japan surpasses the United States by a wide margin. In addition to an official reporter, over half a dozen widely circulated national periodicals regularly report with commentary major (and many unofficially reported) decisions by courts at all levels. Lower court decisions are also available today on the internet. With nearly three times as many law students (both undergraduate and postgraduate in Japan's new law schools) as in the United States (postgraduate) on a per capita basis, the percentage of the population with at least basic legal educationespecially with respect to private law - is considerably greater in Japan. Almost every corner bookstore stocks up - to-date commentaries on private law (the Civil Code) for the student market. Although the number of licensed lawyers in the U.S. is twenty - five times greater than that of licensed lawyers (bengoshi) in Japan, the number of university-educated economic actors with legal expertise in Japan far exceeds that in the United States.

These factors in combination facilitate the application of legal rules in both the ex ante negotiation of agreements as well as ex post settlement of disputes. In other words, they make "bargaining in the shadow of the law" less costly by reducing the need for specialized legal services and thus more likely. Although unfortunately not comparative, Mark Ramseyer's studies confirm propensity in Japan to reach agreements in both instances in conformity with applicable legal rules.24 Low litigation (as well as arbitration) rates in Japan thus do not evidence either the irrelevance of legal

24 See J. Mark Ramseyer \& Minoru Nakazato, The Rational Litigant: Settlement Amounts and Verdicts in Japan, 18 J. LEGAL STUD. 263-90 (1989); J. Mark Ramseyer, Legal Rules in Repeated Deals: Banking in the Shadow of Defection in Japan, 20 J. LEGAL STUD. 91-117 (1991). 
rules or a propensity to avoid litigation when advantageous.

With respect to the United States, a similar degree of predictability is simply not possible. Variations of outcome in like cases are simply too great in comparison in terms of jury awards as well as decisions by individually independent judges to allow the degree of certainty and predictability available in Japan. ${ }^{25}$ The added variations of state law and limited access to legal expertise make legal outcomes less predictable.

\section{The Law}

Not only are the legal rules-including judge-make rules - more certain and accessible in Japan, the rules themselves favor the enforceability of ex ante agreements. First the rules related to formation arguably bring a wider array of agreements under protection as binding commitments. As in other civil law jurisdictions, Japanese contract law recognizes the enforceability of promises without formality - no statute of frauds?and without consideration. Kawashima's views taken at face value, vaguely worded commitments do not necessarily defeat contract claimants. Prevailing patterns of judicial fact-finding and interpretation tend to support enforcement of even vaguely worded agreements based of determinations of the parties' actual expectations at the time of agreement. 26 With respect to performance, Japanese courts continue to emphasize a pacta sunt servanda approach. To illustrate these points, I offer an extended analysis of Japanese case law related to supervening events and termination of longterm contracts. The law as developed by the courts in both areas, I submit, confirms the extraordinary continuity and predictability of Japanese contract law. Both also provide context for Kawashima's observations regarding the unease some Japaneseparticularly those with ex ante bargaining leverage who perceive that they will retain that bargaining advantage throughout the relationship. For those with continuous bargaining leverage over the course of the relationship, the sort of enforceable contract rights so appealing to developmental economists may not be at all advantageous. Moreover, in light of the certainty of judicial enforcement of contracts, Kawashima's description of Japanese attitudes toward avoidance of binding ex ante contractual may

25 See Eric Moller, Trends in Civil Jury Verdicts: New Data From 15 Jurisdictions, Rand InstituTe For CiviL JUSTTCE RES. BRIEF 9025 (1996), http://www.rand.org/pubs/research_briefs/RB9025/ (last visited on Jan. 29 2008).

26 See Willem M. Visser 'T Hooft, JAPANese Contract AND ANTI-Trust LAW 46 (2002), noting the tendency in Japan as implicitly compared with the Netherlands for a broader exercise of discretion by judges to find intent. 
have also been quite accurate with respect to parties who wish mutually to avoid ex ante commitments that preclude either party from unilateral defection in light of changed circumstances. In both instances, however, the parties bargain the shadow of relative certainty.

\section{Supervening Events as an Excuse for Non-Performance}

Supervening Events will relieve a party from the duty to perform a contractual commitment under two doctrines of Japanese private law: (l) impossibility of performance (rikō funo) as a result of circumstances that are not attributable to he fault of the obligor (promisor) and (2) the principle of changed circumstances (jijō henkō no gensoku). Neither the relationship between these doctrines nor their prerequisites or effect have been fully defined by either judicial precedent or scholars. Most relevant decisions date back to the period just before and after World War II.27

Impossibility of performance of a contractual obligation exculpates an obligor's breach unless such impossibility arises out of circumstances attributable to his fault. This conclusion results from a generally accepted construction of Article 415 (1) of the Civil Code, which provides:

If an obligor fails to effect performance in accordance with the tenor and purport of the obligation, the obligee [promisee] may demand compensation for damages; the same shall apply where performance becomes impossible as a result of a cause attributable to the fault of the obligor.

The Code' s risk of loss provisions for sales are to similar effect. Article 536 provides:

a. Except in the cases referred to in the preceding two articles, if the performance of an obligation becomes impossible for any cause not attributable to the fault of either party, the obligor shall not have a right to receive counter-performance.

b. If performance becomes impossible for any cause attributable to the fault of the obligee, the obligor shall not lose his right to demand counter-performance; however, if he has received any benefit through being relieved of his own obligation,. he shall return such benefit to the obligee. 
Article 415, it should be noted, is construed in light of other provisions of the Code and a significant dose of German law theory to pivot both discharge and liability for breach on the idea of impossibility. Performance is discharged if impossible for a cause not attributable to the fault of the promisor. If, on the other hand, performance becomes impossible for a cause that is attributable to the promisor' s fault, the promisor remains liable. However, until performance, including court-ordered specific performance, becomes impossible (or the promisee rescinds the contract, for instance, under Articles 540-548 of the Code), the promisee has only the right to demand specific performance and delay damages. Thus only one of two functions of "impossibility of performance" is to discharge the promisor. The requirements for such discharging impossibility are (1) that the performance be "impossible" and (2) that this impossibility result from a cause not attributable to the fault of the party seeking discharge.

What then constitutes impossibility? A rather elastic standard is said to apply in all contexts, but there is evidence that Japanese courts in practice construe the requirements at least for discharging impossibility rather severely. The applicable standard is said to be "the commercial sense of society" (shakai no torihiki gainen).28 The leading case, Ota $v$. Koji, 29 reflects what was in effect an overruling of 1904 decision by the Great Court of Cassation (the prewar appellation for the Supreme Court), 30 in which absolute physical impossibility, not merely hardship, was held to be required.) The "commercial sense of society" arguably provides the courts with a type of standard that is possible to manipulate to reach almost any result that a court feels warranted in a particular case. The same flexibility that makes such a standard so apparently useful to the courts also makes any attempt at assessing the legal effect of a particular set of circumstances very difficult, especially in the Japanese context where the litigated answer is likely to quite tardy.

Two of the best studies available in any language on impossibility in Japanese law in English date from the 1960s. 31 The authors in both conclude that existing precedents indicate that Japanese courts are relatively liberal in allowing discharge and that the Japanese rules are roughly equivalent with the idea of impracticality because of the extreme and unreasonable difficulty, expense, injury or loss involved under the UCC $\S 2-615$. The language and standards used by Japanese courts to some degree bear out this conclusion. It is submitted, nevertheless, that Japanese courts, at least at the level of

\footnotetext{
Ota v. Koji, 19 Minroku 327 (Gr. Ct. Cass., May 12, 1913); 4 Wagatsuma, Hanrei Kommentaru 81 (1965).

Ota v.Koji, id.

Veda v. Matsuda, 10 Minroku 1453 (Gr. Ct. Cass., Nov. 15, 1904).

31 Sawada, supra note 3; Igarashi and Luverne Reike, Impossibility and Frustration in Sales Contracts, 42 WASHINGTON L. REV. 445 (1967).
} 
the Supreme Court, have yet to reach a decision that warrants the label "liberal exculpation" in terms of the factual pattern and situation of the cases that have been reported. Past decisions are sufficiently consistent to allow predictable guidance. Once applied, the ostensibly vague "commercial sense of society" has become remarkably resistant to change. For over a century, for example, the courts have consistently held in the context of raw material shortages that performance is not impossible for reasons not attributable to the fault of the promisor unless raw materials are unavailable at almost any price.

The bulk of the relevant cases were decided immediately prior and in the wake of defeat after World War II. They held that extreme hardship, although not the absolute impossibility of locating vessels constituted discharging impossibility under the standard. 32 Shortages of iron as a result of export restrictions, lack of vessels, and war were similarly held to discharge a shipbuilder from a contractual commitment to deliver a ship 33 Although there is little in the way of detailed analysis of the facts, in all of these cases performance was precluded by more than commercial impracticality. In each case the discharged party was, after apparently some effort, unable in fact to procure the required ships or supplies. Furthermore, there is no indication in any of these cases that the courts equated economic hardship or loss with "extreme hardship". In fact, it is possible that the ships and iron could not have been obtained at any price at that time.At least one early lower court decision determined the issue of impossibility by explicit balancing of economic gain and loss. In this case - Hasegawa v. Hakodate Senkyo K.K.34 - a shipowner successfully claimed damages against a salvage company for failure to perform a salvage contract. While being towed by the defendant company, the vessel sank again as a result of high waves. The court found that it was "impossible" to salvage the ship pursuant to the contract because any benefit to be gained by the shipowner was outweighed by the costs involved in a second attempt to refloat the vessel. The Hasegawa case, however, did not involve discharging impossibility. A finding of impossibility was necessary in that case to support the shipowner's claim for damages.

A 1951 lower court decision 35 has language that suggests commercial impracticality or economic loss could constitute discharging impossibility. But in this case too the facts cluster closer to the absolute end of the impossibility continuum. The case involved a

\footnotetext{
32 See, e.g., Kuan v. Goshi Kaisha Sei Hatsu To, Hōritsu Shimbun (No. 4702) 56r-TJapan consulate General in Sainan, April 26, 1941): Shibuya v. Goto Gomei Kaisha, Hōritsu Shimbun (No. 4655) 30 (Korea App: C Dec. 3, 1940).

33 Hanrei Taikei 536 (Tokyo App. Ct., June 2, 19-).

34 Hōritsu Shimbun (r-Jo. 827) 24, (Hakodate Dt., Ct., Oct. 9, 1912).

35 Fujisawa v. Nakamura, 2 Kakyu minshū 146 (Nara Dt. Ct., Feb. 6, 1951).
} 
contract made in Korea in 1944 under which Nakamura was to manufacture and supply fishing net dyes to Fujisawa on a continuing basis and a claim by Fujisawa for return of a deposit and damages. The dispute thus arose during the closing months and presumable chaos of the Japanese occupation of Korea. Both parties were Japanese and had returned to Japan following the war. The court held as follows:

Where the amount of the goods and term of the sale in a sales contract for the continuing supply of goods between merchants are not decided upon beforehand, and where, because of circumstances that could not have been foreseen beforehand by either side at the time of the conclusion of the contract, delivery of the contract goods has become difficult and, as for the buyer as well, paying transportation costs has become impossible in terms of profitability within the scope of price controls, we recognize that in the absence of special circumstances to the contrary that to perform the obligations both sides bear in accordance with the tenor of the contract has become actually and economically impossible for reasons that cannot be attributable to the fault of either the seller or the buyer.

Apparently the seller was not able to obtain transportation for the dyes as a result of a freight car shortage and informed the buyer that he could not make delivery unless the buyer provided an alternative means. The buyer did not respond.

The basic standard for negligence determines whether impossibility is attributable to the fault of the obligor - that is, whether the party claiming exculpation has exercised the care required of a person in his position to avoid impossibility. ${ }^{36}$ The burden of proof ordinarily is on the party claiming discharge.

Discharging impossibility is sometimes treated as identical to the concept of force majeure (fuka koryoku). The term is expressly used in several separate provisions of the Japanese Civil and Commercial Codes. 37 and it seems more appropriate to conclude that force majeure is a more limited concept that is included in the idea "impossibility for a cause that is not attributable to the fault of the obligor." Common to both concepts, however, is the notion that a party is not discharged by impossibility caused by an external supervening event if the event could be foreseen and its consequences could have been avoided by taking proper precautions. What measures must be taken will depend in turn on the standard of care required by the party in the circumstances of the case. Thus in Hasegawa case the court found that the bad weather conditions were foreseeable and the resinking of the salvaged ship could have been prevented if proper

36 See Sakae Wagatsuma, Hanrei Kommentaru 83 (1965).

37 Civil Code articles: 274, 275, 348, 419, 609 and 610; Commercial Code articles: 576, 594, 741, 756, 761, 782, 799, 821, 832 and 825. 
care had been taken. It thus held that the high waves and weather conditions did not constitute force majeure that would excuse nonperformance by the salvage company. In contrast, in Vacuum Oil Co. v. Dampfsschiffsreederei Union A.G. (1910),38 where a carrier was sued for loss of oil during transport, the Court held that the loss was the consequence of bad weather and high waves and could not have been prevented by the exercise of care required of a party in those circumstances. In short, the weather conditions constituted discharging force majeure.

Should the event causing impossibility occur while a party is in delay, the ultimate impossibility of performance can almost always be attributable to the fault of the party responsible for delay to the effect that he is not excused from nonperformance (breach). For instance, in the 1906 decision in Watanabe v. Mizumi, 39 the Court held that performance was impossible for reasons attributable to the fault of the seller and awarded damages under Article 415. The decisive fact was that the statute creating the Japan Tobacco Monopoly, making private trading in tobacco illegal, had been enacted during the defendant's delay in making delivery under a private sale of tobacco products.

Underlying the courts' restricted application of the Civil Code provisions on discharging impossibility is an implicit emphasis on the pacta sunt servanda principle. Strict enforcement of contractual duties in turn led to the development of the doctrine of changed circumstances. In the mid 1920s Japanese scholars, primarily Professor Katsumoto, favorably impressed by the use of the Geschäftsgrundlage theory in Germany and imprévision in French law during the economic chaos that followed World War I, introduced the doctrine of changed circumstances. The doctrine was cast principally in terms of the requirements of the good faith and fidelity required of parties to a contract. (Developed initially by the courts, the good faith principle was incorporated into the Code under Article 1(2), as noted, only after the end of the World War II.) As interpreted by scholars and court decisions, a contract party has the right to require an adjustment of the terms of the agreement or, if no mutually compromise can be reached, to rescind the contract where (1) there has been a change of circumstances, that (2) has occurred after the contract was concluded but prior to the time for performance, (3) could not have been foreseen by the parties, (4) is not attributable to the fault of either party, and (5) renders performance under the terms of the contract unconscionable. 40

The Great Court of Cassation first recognized the doctrine in 1944 in Okunokoji v.

3816 Minroku 807 (Gr. Ct., Cass., Nov. 25, 1910).

3912 Minroku 1358 (Gr. Ct. Cass., Oct. 29, 1906).

40 See Katsumoto, [Business contingencies of enterprises and the principle of change of circumstances], NBL (No. 55) 6 (1974). 
Ichida,41 The parties had concluded a contract in 1939 for the sale of land on which the plaintiff intended to build a factory. After the plaintiff had made the down payment but prior to the subsequently extended date for final payment, July 31, 1941, price control regulations were enacted in 1940 that made mandatory official approval of the purchase price. Although the defendant made proper application on July 9, 1941, no decision had been reached by the date for payment, and registration of ownership was not transferred. The plaintiff thereupon notified the defendant of his intention to rescind the contract on August 1, 1941 and to claim return of the down payment. The court held that under such circumstances the buyer might be entitled to rescind, for it would be contrary to the principle of good faith to require the parties to be bound by the contract for a long period of uncertainty. Thus the court reversed the judgment below and it remanded the case to the court below ordering it to determine when the official approval would have been expected at the time of the notification of rescission.

Although the doctrine of changed circumstances has been recognized as applicable law in subsequent cases, Okunokoji v. Ichida remains the sole reported decision by the highest Japanese court in which relief under the doctrine has been afforded. The Japanese Supreme Court also seems to have consistently refused to relieve contract parties from losses due to inflation even where the value of the contract has bee reduced to almost nothing.

This is not to say that all cases are decided with perfect consistency. Under similar circumstances $\mathrm{s}$ few lower court decisions have required price adjustments 42 or have allowed rescission. 43 As a Dutch scholar observed, the decisions of lower courts have not been "univocal" in either Japan or the Netherlands. 44 Nonetheless, I submit, one would be hard pressed to find equivalent consistency of judicial decisions on issue of U.S. law over the course of a century.

\section{Termination of Long-Term Contracts}

Despite strong adherence to party autonomy and freedom of contract, the courts do not in all instances enforce all contract terms. Through contract interpretation as well as the application of the good faith and abuse of rights doctrines in particular instances the

\footnotetext{
4123 Minshū 613 (Gr. Ct. Cass., Dec. 6, 1944).

42 See, e.g., Oba v. Endo, 9 Kakyu Minshū 666 (Sendai High Ct., April 14, 1958), setting an original resale price of 520 yen at the tax assessment of 64,070 yen or the fair market value of 324,000 yen.

43 See, e.g., Ideguchi v. Ishikawa, 3 Kakyu Minshū 791 (Nagasaki Dist. Ct., June 9, 1942).
} 
courts have limited their enforcement of what may appear to be clearly stated provisions. In such instances too, however, the rules although perhaps malleable are nonetheless predictable. Take, for instance, clauses allowing unilateral termination.

Under long-accepted judicial decisions, a party to a long-term, on-going business relationship could unilaterally terminate only with justification. This limitation on party autonomy conformed to a consistent pattern of judicial decisions in other contexts, including marriage and divorce, leaseholds, and employment in which the courts provided legal protection against unilateral termination of a long term relationship of dependent parties. 45 Commercial dealings never received the same sort of scrutiny, however, where the relationship involved a potentially significant degree of economic dependency with subsequent injury if terminated unilaterally, the courts had as in other instances required "just cause" or a negotiated, mutually agreed termination. The provisions of the contract mattered. The requirements for justification have been generally more stringent in the absence of any express agreement to the contrary. Termination at the end of the contract term has been easier to justify than termination of contracts without a term. Contracts with or without stated terms are not, however, unilaterally interminable. Japanese law does not deny the right of either party at some point in time unilaterally to end the relationship, especially at the end of the contract' $s$ express term (by non - renewal) or otherwise in accordance with express provisions.

The courts have recognized a variety of commercial considerations and other factors to justify termination under various rubric, used interchangeably in some cases, most commonly "compelling" or "unavoidable reasons" (yamu o enai jiy $\bar{u}$ ) but also "reasonable grounds" (gōri-teki na riy $\bar{u}$ ) and "good reason" (seitō na riy $\bar{u})$. The economic relationship between the parties is the critical factor. Two categories of conduct the part of the party subject to termination are especially apt to justify unilateral termination. The first encompasses acts that are inconsistent with "mutual trust" and fair commercial dealings, including breach of contract. The second includes conduct that increases the commercial risks of the party seeking to end the relationship, such as failure to make timely payments. The motives of the party seeking to terminate the relationship also have significant bearing. Thus examples of unjustified unilateral termination would include sellers attempting to take advantage of distribution networks developed by long - term distributors or by manufacturers seeking to terminate long-term sales relationships with explicit provisions on pricing with less efficient suppliers in order to acquire less costly raw materials. Unilateral termination is thus more difficult to justify to the extent that the party being terminated is unable to recover investment made with

44 Visser 't Hooft, supra note 22, at 41.

45 See Haley, supra note 21, at 123-55. 
the expectation of continuation of the business relationship or is economically dependent on the commercial relationship. Unilateral termination is also more difficult to justify where the parties have continued to do business together without any formal contractual arrangement over a long period of time than where the contract has a fixed term. Similarly Japanese courts tend to allow unilateral termination so long as the terminating party gives adequate notice. One of the best known cases is the 1987 Sapporo High Court decision in Hokkaidō Ford.

Hokkaidō Ford Tractor K.K.46 is among the most important recent decisions on termination of long - term, continuous business relationships. The case involved the attempted non-renewal of an exclusive distributorship. The defendant manufacturer of farm equipment had entered into an exclusive dealership for farm equipment with the plaintiff in 1971 covering the northern island of Hokkaido. The original agreement provided for annual renewal unless either party gave three moths notice for revision or cancellation. A new contract was concluded in 1982 but the renewal provision was not changed. Because of lagging sales in farm equipment generally, the manufacturer decided to reorganize its distribution and notified the plaintiff of its intention to terminate the dealership. The dealer protested and filed suit seeking provisional injunctive relief. The Sapporo District Court decided in favor of the defendant and the plaintiff appealed. On appeal, the Sapporo High Court reversed and granted the injunction. The high court determined that the manufacturer did not have "unavoidable reasons" to terminate the contract given the plaintiff $s$ dependency on the dealership. The court observed that a one-year term was too short for any dealership to be commercially feasible-at least three to five years was necessary. In addition, the plaintiff had made a substantial investment and devoted considerable effort to the dealership. The court also emphasized the plaintiff's economic dependency, explaining that it would face considerable difficulty in finding any alternative dealership because most farm equipment manufacturers had already established exclusive distribution networks. The court also noted that the defendant had profited from the plaintiff s efforts and questioned whether the cancellation made commercial sense given the plaintiff s prospective loss.

A decade later the Osaka High Court faced the same question and similarly decided K.K. Ferox v. K.K. Aloins Cosmetics. 47 In that case a cosmetics manufacturer had terminated a sales contract with a wholesaler pursuant to clause that provided for automatic annual renewal subject to 30 days notice of the intent by either party to

46 Hanrei Jihō (No. 1258) 76 (Sapporo High Ct., Sept. 30, 1987).

47 Hanrei Jihō (No. 1612) 62 (Osaka High Ct., Mar. 28, 1997), affirming on different grounds K.K. Ferox v. K.K. Aloins Cosmetics, Hanrei Jihō (No. 1566) 85 (Osaka Dist. Ct., Nov. 7, 1995). 
cancel. The parties had been doing business together for more than 10 years. The district court invalidated the attempted termination on the grounds that the manufacturer was attempting to maintain retail price in violation of the Antimonopoly Law prohibition against vertical price-fixing. The Osaka High Court disagreed on the Antimonopoly Law issue but upheld the judgment against Aloins Cosmetics on the grounds that the cancellation was invalid for lack of the necessary justification ("compelling" or "unavoidable reasons") for terminating long - term, business relationships. Apparently the contract did not contain any provision restricting distributors from selling to discounters. No breach was alleged or argued. (The defendant did argue that the plaintiff had made late payments.)

Two recent cases suggest a possible change. The first, Egawa Kikaku K.K. v. Kao K.K,48 involved a standard form contract concluded in 1988 between Kao K.K., a leading cosmetics manufacturer and Egawa Kikaku K.K., a small retailer in Sendai, Japan. The contract provided for a one-year term automatically renewable unless either party gave the other 30 days notice of its intent to cancel. The contract was renewed annually for three years. Believing that Egawa, which was purchasing an increasingly large volume of Kao cosmetics, was selling to discounters, on June 2, 1992 Kao sent Egawa notice of its intent to cancel as of July 2, 1992. No reason was given. Kao's suspicions were later confirmed. Egawa Kikjaku had been selling to Fujiki Honten, a major Japanese cosmetics discounter. In the meantime, Egawa filed suit charging that Kao had breached its contract with Egawa because the cancellation as invalid as an abuse of rights and unfair business practice under Article 19 of the Japanese Antimonopoly Law. The Tokyo District Court agreed and issued a judgment requiring Kao to fill Egawa's existing orders.

On appeal the Tokyo High Court reversed. The court upheld Kao's right under the express provisions of the contract to cancel without reason. The court found no abuse of right nor violation of either the good faith principle or any mandatory law, such as the Antimonopoly Law ${ }^{49}$. Although the court concluded that despite the lack of any express provision in the contract the parties had in fact agreed that the agreement imposed a duty on Egawa to sell directly (face to face) to consumers and prohibited resales of the products to other retailers both of which duties Egawa had breached, by the express terms of the contract no reason or justification for cancellation was required. In a terse

48 Egawa Kikaku K.K. v. Kao K.K., Hanrei Jihō (No. 1664) 3, (Sup. Ct., 3rd P.B. Dec. 18, 1998), affirming Kao K.K. v. Egawa Kikaku K.K., Hanrei Jihō (No.1624) 55 (Tokyo High Ct., July 31, 1997), reversing Egawa Kikaku K.K. v. Kao K.K., Hanrei Jihō (No. 1500) 3 (Tokyo Dist. Ct., July 18, 1994).

49 Shiteki dokusen oyobi kōsei torihiki no kakuho no kansuru hōritsu (Law concerning the prohibition of private monopoly and maintenance of fair trade] (Law No. 54, 1947). 
sentence the court stated that the requirement for "compelling" or "unavoidable reasons" for non-renewal of a continuous business relationship did not apply. On second appeal, the Third Petty Bench of the Supreme Court affirmed.

The second case, decided the same day also by the Third Petty bench, was Fujiki Honten K.K. v. Shiseido K.K.50 It involved a standard form "chain store" contract concluded in 1962 between Shiseido K.K., Japan' s leading cosmetics manufacturer, and Fujiki Honten, at the time a small retail cosmetics store in Tokyo. The contract has a one-year term but was expressly automatically renewable unless either party gave the other 30 days notice. The contract also required Shiseido's retail customers to sell only on a face-to-face basis. Fuji's owner introduced a system of direct sales to office employees, offering a 20 percent discount. The result was rapid expansion of Fujiki s business, which continued despite objections over discounts by Shiseido representatives. In the mid 1980s Fujiki next introduced catalogues for its "office sales" that included various Shiseido products. Shiseido objected and sent a warning letter demanding that Fujiki discontinue inclusion of Shiseido products. Fujiki refused. After failing to reach a negotiated settlement, in April 1990 Shiseido sent Fujiki formal notice if its intent to terminate at the end of 30 days. Fujiki then filed a complaint with the Japanese Fair Trade Commission, charging Shiseido with engaging in unfair business practices. The JFTC declined to act. Thereupon Fiji filed suit seeking a declaratory judgment that Shiseido's unilateral termination was invalid and confirmation of its rights under the agreement, including right to receive shipments of cosmetics from March 1990 to June 1991. The Tokyo District Court granted the relief Fujiki sought, finding that inasmuch as the parties had had a long - term, continuing relationship the contract could not be unilaterally terminated by Shiseido without "compelling" or "unavoidable reasons" Shiseido' s attempt to cancel was deemed invalid as a violation of the good faith principle. The court also held that the restrictions in the contract requiring face-to-face sales constituted an unfair business practice in violation of the Antimonopoly Law. On appeal by Shiseido the Tokyo High Court reversed. The high court found that, given the continuous 28 years of business between the two companies, unilateral termination required justification (an "unavoidable" or "compelling reason"). The court then found that the provision requiring "face-to-face" sales was commercially reasonable and its breach provided Shiseido with sufficient justification to exercise the express contractual provision for termination with 30 days notice. The court dismissed the argument that the restriction violated the Antimonopoly Law. On

50 Fujiki Honten K.K. v. Shiseido K.K., Hanrei Jihō (No. 1664) 3 (Sup. Ct., 3rd P./B., Dec. 18, 1998), affirming Shiseido K.K. v. Fujiki Honten K.K., Hanrei Jihō (No. 1507) 43 (Tokyo High Ct., Sept. 14, 1994), reversing Fujiki Honten K.K. v. Shiseido K.K.., Hanrei Jihō (No. 1474) 25 (Tokyo Dist. Ct., Sept. 27, 1993). 
appeal to the Supreme Court, as noted above, the Court affirmed the high court decision, finding no violation of the Antimonopoly Law but without mention of the validity of the unilateral termination.

The failure of the Supreme Court either to confirm or reject the change suggested by the Tokyo High Court decisions in Kao and Shiseido (the better known parties) exemplifies the judiciary's characteristic adherence to precedent and cautious approach to legal change. Change does occur, but it occurs gradually and predictably, reinforcing a deeply embedded commitment to certainty and consistency.

\section{Enforcement}

An array of hurdles hinders any assessment of the comparative Japanese or U.S. advantage in terms of the enforcement of contract rights. A lack of comparable statistical data leads necessarily to reliance on less conclusive analyses and informed speculation. One conclusion can be drawn with greater certainty than most others: U.S. courts have considerably greater capacity to enforce their judgments and orders. Another is equally certain. With respect to contract enforcement, Japanese are not loath to litigate. They have long used the most effective and efficient judicial processes for contract enforcement available to them-the procedural mechanisms for provisional remedies, which include provisional attachment (kari-sashiosae) and provision injunctions (kari shobun), are currently set out in the Civil Provisional Remedies Law of $1989^{51}$ and the Civil Provisional Remedies Rules of 1990.52 In absolute numbers, filings for provisional remedies have been historically quite significant, representing by one estimate over ten percent of all civil cases until the expansion of dramatic expansion of ordinary suits in the late 1970s.53 Courts in these cases make findings of fact and law and thus allow for a less costly and more timely adjudication, which in turn facilitates settlement.

Since the late 1970s, litigation rates have increased, surpassing prewar levels. Although still relatively low by international standards, the number of civil actions filed per judge remains one of the highest in the industrial world. 54 More telling than relative litigation rates is the extraordinary ability of Japanese judges to reduce delays in the face of mounting caseloads in courts at all levels. I have suggested previously that based on

51 Minji Hozen Hō (Law No. 91, 1989).

52 Minji Hozen Kisoku (Supreme Court Rules No. 3, 1990).

53 Wollschläger, supra note 11, at 126 (Fig. 10).

54 In 1971, judges issued nearly 60,000 judgments in fully litigated first instance civil cases. 
prewar patterns a compelling case can be made that the reduction in delay has been a causal factor in this increase. 55

Japan loses its advantage, however, in the formal enforcement of judgments. Unfortunately no comparative data on law enforcement exists, but both U.S. and European scholars who have studied the issue agree: European and U.S. courts generally enjoy more effective powers than their Japanese counterparts. 56 Japan has, however, well developed private sector substitutes. I and others have examined the role of organized crime as the "dark side" of private enforcement. ${ }^{57}$ Japanese clearing house rules requiring banks to terminate all transactions with parties who fail to honor checks and promissory notes have made promissory notes a form of collateral and effectively deter default. 58 Reputation and trust also play a key role. Thus even with respect to enforcement, in the end perhaps the United States does not have so much of an advantage.

\section{Kawashima Reconsidered}

The conclusions reached by Macaulay and Kawashima rest on very different assumptions. Macaulay emphasized the transactions costs of formal contracting and uncertainty of enforcement that reduced the efficacy of ex ante commitments. For Kawashima, on the other hand, the avoidance of formal contact appears to be based on a desire to avoid the enforcement of ex ante commitments by those who perceive that their bargaining leverage will remain intact throughout an on-going business relationship, thus enabling them to adjust unilaterally to changing circumstances. Thus on closer examination, Kawashima may have been correct after all. Japanese parties with superior bargaining positions or who are able to dominate on-going private ordering arrangements have good reason to find enforceable ex ante contractual commitments "unsettling". Similarly ex ante contractual commitments may also be

55 See Haley, supra note 21, at 134.

56 See Frank G. Bennett, Jr., Civil Execution in Japan: The Legal Economics of Perfect Honesty, NAGoYA J. L. \& PoL. (No. 177) 1 (1999); Visser 't Hooft,, supra note 22, at 45.

57 See, e.g., John O. Haley, Authority Without Power: LaW and the Japanese Paradox 183-6 (1991); Curtis J. Milhaupt \& Mark D. West, The Dark Side of Private Ordering: An Institutional and Empirical Analysis of Organized Crime, 67 U. CHI. L. REv. 41 (2000).

58 See Haley, id. at 183. J. Mark Ramseyer \& Minoru Nakazato, JAPANESE LAW: An Economic ApProACH 62 (1999); Marc Ryser, Sanctions Without Law: The Japanese Financial Clearinghouse Guillotine and its Impact on Default Rates (unpublished paper, 1993). 
viewed as less advantageous to those who may have the disadvantage in bargaining leverage at the time of the contracting to the extent that they perceive that they may gain greater ex post leverage. Thus the Japanese advantage itself may be the undoing of formal contracting. 